\title{
Effect of foliar nutrition on growth, yield and quality of chickpea (Cicer arietinum L.)
}

\author{
V. G. TAKANKHAR, P. N. KARANJIKAR AND S. R. BHOYE
}

Received : 11.08.2017; Revised : 12.11.2017; Accepted : 21.11 .2017

MEMBERS OF RESEARCH FORUM:

Corresponding author :

P. N. KARANJIKAR, College of

Agriculture, Ambajogai, BEED (M.S.) INDIA

Email: pnk_1972@rediffmail.com

Co-authors :

V.G. TAKANKHAR AND S.R. BHOYE, College of Agriculture (V.N.M.K.V.) LATUR (M.S.) INDIA

\section{Summary}

The field experiment was on effect of foliar nutrition on growth and yield of chickpea (Cicer arietinum L.). It was conducted during Rabi season in the year 2015-16 at the Research farm of College of Agriculture, Latur. The experiment was laid out in Randomized Block Design with three replications and variety "Vijay" as test crop along with eight treatments viz., $\mathrm{T}_{1}$ $\mathrm{RDF}, \mathrm{T}_{2}-\mathrm{RDF}+$ water spray, $\mathrm{T}_{3}-\mathrm{RDF}+19: 19: 19 @ 1.0 \%$ at vegetative stage, $\mathrm{T}_{4}-\mathrm{RDF}+$ 00:52: $34 @ 1.0 \%$ at flowering stage, $\mathrm{T}_{5}-\mathrm{RDF}+13: 00: 45 @ 1.0 \%$ at grain filling stage and $\mathrm{T}_{6}-\mathrm{T}_{3}+\mathrm{T}_{4}$, $\mathrm{T}_{7}-\mathrm{T}_{4}+\mathrm{T}_{5}$ and $\mathrm{T}_{8}-\mathrm{T}_{3}+\mathrm{T}_{4}+\mathrm{T}_{5}$. The results of the field study indicated that, the growth, yield and quality of chickpea was significantly influenced by foliar nutrition. The growth parameters viz., plant height, number of branches, number of pod plant ${ }^{-1}$ and dry matter of chickpea were significantly improved due to treatment $\mathrm{T}_{8}(\mathrm{RDF}+19: 19: 19 @ 1.0 \%$ at vegetative stage, RDF +00:52: $34 @ 1.0 \%$ at flowering stage and RDF+13:00:45 @ 1.0\% at grain filling stage) however, it was followed treatment $\mathrm{T}_{7}(\mathrm{RDF}+00: 52: 34 @ 1.0 \%$ at flowering stage and RDF + 13:00:45@ 1.0\% at grain filling stage). Yield contributing characters viz., seed yield, straw yield and biological yield were also increased significantly with application of foliar nutrients as per $\mathrm{T}_{8}(\mathrm{RDF}+19: 19: 19 @ 1.0 \%$ at vegetative stage $+\mathrm{RDF}+$ 00:52: $34 @ 1.0 \%$ at flowering stage + RDF + 13:00:45 @ 1.0\% at grain filling stage) over rest of the treatments followed by treatment $\mathrm{T}_{7}$.

Key words : Chickpea, Foliar nutrition, Growth, Yield, Quality

How to cite this article : Takankhar, V.G., Karanjikar, P.N. and Bhoye, S.R. (2017). Effect of foliar nutrition on growth, yield and quality of chickpea (Cicer arietinum L.). Asian J. Soil Sci., 12 (2) : 296-299 : DOI : 10.15740/HAS/AJSS/12.2/296-299. 